\title{
Students' Influences of CAA: A Case Study of Senior High School in Badung Bali
}

\author{
I Gusti Ayu Vina Widiadnya Putri \\ Department of English, Faculty of Foreign Language, Mahasaraswati University, Denpasar, Indonesia \\ vina.ayu422@gmail.com \\ ${ }^{*}$ Corresponding Author \\ Whatsapp Number [081238072643]
}

How to Cite: Putri, I.,G.,A.,V.,W (2019). Students' Influences of CAA: A Case Study of Senior High School in Badung Bali. International Journal for Educational and Vocational Studies, 1(1), 1-4. DOI: https://doi.org/10.29103/ijevs.v1i1.1392

\section{ARTICLE HISTORY}

Received: 10 January 2019

Revised: 23 February 2019

Accepted: 7 April 2019

\section{KEYWORDS}

Computer-assisted Assesment (CAA)

Students' ability

English skills

\begin{abstract}
The aims of this study is to find out and analyzed about students' influences of Computer-assisted assessment (CAA) It is the case study and field research of one school in Nusa Dua Badung-Bali. The data sources chosen in this study were several high schools that carried out online examinations at Nusa Dua Vocational high school Bali-Indonesia. Data collection is done by random sampling from data sources, observation, interviews, recording, and note taking. Distribution of questionnaires was also carried out to strengthen data analysis. Data is analyzed based on the formulation of the problem and the study of theory that has been, then analyzed in qualitative description. The descriptive study used paper-based surveys and interviews for data collection. To obtain information about the students' influences of Computer-assisted assessment (CAA). Based on our review and study result, there are some influences that found. The Computer-assisted assessment (CAA) systematics is held with the aim that students become more critical and independent in solving the questions given.
\end{abstract}

This is an open access article under the CC-BY-SA license.

\section{INTRODUCTION}

The use of technology nowadays needs to be important. It can replace conventional methods by paper based assessment with the use of technology is needed by everyone. Earlier research has shown a range of motivations for implementing CAA in a course, and often a combination of factors result in CAA being used (Bull \& McKenna, 2001). Nolan and Martin (1994) stated that learning in new environments such as using the internet in schools has made many influences for the students. The students will be more adept at making judgments and thinking more critically. Nonetheless, socio-economic conditions among students must take approximately during the exposure of computer and internet technology to be provided (Bier et. Al, 1996). Teachers will find it easy to identify students and schools will be more well-known among the public because of the assumption that people prefer schools with highly advanced technology. Although the costs incurred by schools or educators are not cheap because current technology is very expensive. The curriculum is holistic where knowledge, skills and values (values) are integrated with information needs in competency-based curriculum.

Over the past decade there has been a large increase in the use of computer-based assessment (Stephens \& Mascia, 1997). Computer based assessment is a process of systematically gathering evidence and making decisions about a person's behavior towards established competency standards. Assessments should be interconnected between skills, knowledge and attitudes and useful applications, candidates/examiners must show that they are competent in all tasks, not just partially. Appraisal based on competence is not only about performance, knowledge and understanding are fundamental to performance and the need to be assessed. Assessment in learning is a formal process or effort to gather information related to important variables of learning as material in decision making by teachers to improve the process and student learning outcomes.

Schools make it easier for teachers and students to use structured and scheduled teaching materials or learning instructions through the internet, so that both can assess each other to what extent the teaching material is learned. Students can learn or review teaching materials at anytime and anywhere if necessary considering the material teaching is stored on the computer. When students need additional information related to the material they are 
studying, they can access the internet. Both teachers and students can hold discussions through the internet which can be followed by a large number of participants, thus increasing knowledge and insight large. Changing the role of students from usually passive to active.

Based on the above exposure, there is a curiosity to find out and analyze how online examinations were conducted in formal schools and what are the influences of the online exam itself for teachers and students.

\section{METHODS}

Computer-assisted assessment (CAA) encompasses a range of activities, including the delivery, marking, and analysis of all or part of the student assessment process using stand-alone or networked computers and associated technologies. Earlier research has shown a range of motivations for implementing CAA in a course, and often a combination of factors result in CAA being used (Bull \& McKenna, 2001). The data sources chosen in this study were several high schools that carried out online examinations at Nusa Dua Vocational high school Bali-Indonesia.

The choice of high school in Badung regency because this area already has good internet access. This school has been conducting online examinations for the past two years. The subject was English in 10 Grade students. English is a subject that has four skills in competency such as; listening, speaking, reading and writing. Therefore, online competence can be implemented properly. Data collection is done by random sampling from data sources, observation, interviews, recording, and note taking. Distribution of questionnaires was also carried out to strengthen data analysis. Data is analyzed based on the formulation of the problem and the study of theory that has been, then analyzed in qualitative description.

\section{RESULTS AND DISCUSSION}

The Computer-assisted assessment (CAA) systematics is held with the aim that students become more critical and independent in solving the questions given. The other valued features were simplicity of testing, comfort, speed, simplicity of editing and alterations, effective measure of learning outcomes, and reduced anxiety (Karakaya, 2001). The implementation of Computer-assisted assessment (CAA) begins with each student required to log in with their names and numbers absent, then look for subjects to be tested. Students only have 20 minutes for 40 questions in the Examination in one subject tested. If within 20 minutes students have not finished working on all the questions, the system will stop automatically. So the time allocation given in one question is only 30 seconds.

Students are required to read carefully the questions and answers that will appear on the computer screen. The questions and descriptions of answers that will appear on the student's computer screen will be different from the questions and descriptions of answers to other friends. So that students will only focus on answering questions that appear on each computer screen. After students complete the exam within the allotted time, the students then close the question system and then save it. After student answers are stored in the system, students can wait 10 seconds to find out the results after the system corrects automatically. After 10 seconds, the results of the students working on the exam questions will be immediately visible on the computer screen. The amount of information comfortably presented in a computer display is only about one third of that presented by a standard sheet of paper. For example, Haas and Hayes (1986) reported that when a text passage associated with a test item required more than one page, computer administration yielded lower scores than paper-and-pencil administration, apparently because of the difficulty of reading the extended text on-screen.

1. The following is a sample of the results of the Computer-assisted assessment (CAA) in English Language Subjects, in a semester of school year 2018-2019.

Table 1. In X (ten) TB (Culinary Department) 1 Grade students

\begin{tabular}{lll}
\hline Highest score : 78 / Good & Graduation level & sick : - \\
\hline Lowest score : 65 & Pass : 30 students & Permission : 0 \\
\hline Average : 70 / Good & Not pass : 11 students & Alpha : - \\
\hline
\end{tabular}

Based on the data of the evaluation results that have been carried out, as many as 30 students received satisfactory grades and graduated in English language units. 11 other people still need enrichment and remedial action. Based on the upper class XTb1 value data, the highest score obtained by students is 78 in good category and the lowest score of students is 65.00. This shows that students have been able to absorb the lessons that have been obtained previously, given within one semester, there are still some students who have not been able to complete the exam with good grades. By looking at the data sample for the X TB 1, it can be concluded that the teaching and learning process that has been carried out for one semester can be completed successfully.

Table 2. In X (ten) TN (Business Management Department) 1 Grade students

\begin{tabular}{lll}
\hline Highest score : 78 / Good & Graduation level & sick : - \\
\hline Lowest score : 60 & Pass: 29 students & Permission : 0 \\
\hline Average : 72/ Good & Not pass: 9 students & Alpha : - \\
\hline
\end{tabular}

Based on the data obtained from the XTN1 class students, it can be concluded that of the 29 students who have taken the online exam in English subjects, seven of them still need remedial learning and enrichment to increase their knowledge. While 22 others have completed their exams with good value categories and declared graduated. Judging from the data above, as many as 22 students have met the minimum standard of completeness in English with the lowest value of 68.00 categories and the highest score of 78 with the Good category. 
Table 3: In X (ten) AP (Hotel Accommodation Department) 1 Grade Student

\begin{tabular}{lll}
\hline Highest score : 78/Good & Graduation level & sick : - \\
\hline Lowest score : 65.3 & Pass : 31 students & Permission : 0 \\
\hline Average : 71/Good & Not pass: 9 students & Alpha : - \\
\hline
\end{tabular}

Based on the results of the tests that have been conducted in X (ten) AP (Hotel Accommodation Department) 1 Grade Student., it can be concluded that, as many as 31 have reached the minimum criteria for the English language subject with the Good value category. The data above shows that the results of student evaluations have reached minimum completeness, with the highest score obtained by students of class X TB 2 is 78 with good categories, while the lowest value of students is 65.30 with sufficient categories. Of the 40 students who took the online examination of English language acquisition in $\mathrm{X}$ (ten) Grade, 9 students still needed remedial learning and material enrichment. Remedial learning can be carried out by giving a brief repetition of the material, then holding an online evaluation again, with the same weighting. After students can achieve the minimum completeness score, the students can be given enrichment material to increase knowledge about English language acquisition.

\section{Student' influences of online assessment.}

Based on the results of interviews that have been carried out to students about evaluating online learning, there are several statements as follow:

Table 4. Students' influences on online assessment

\begin{tabular}{lcccccc}
\hline \multicolumn{1}{c}{$\begin{array}{c}\text { Evaluation of user influences towards } \\
\text { Computer-assisted assessment (CAA) }\end{array}$} & \multicolumn{5}{c}{ Percentage (\%) } \\
& 5 & 4 & 3 & 2 & 1 \\
& & & & & \\
& & & \\
Increase the score & 46 & 12 & 16 & 16 & 10 \\
\hline Help me to learn the subject by using this & 53 & 10 & 26 & 7 & 4 \\
system & & & & & \\
\hline Increase the four skills in English. & 28 & 25 & 25 & 15 & 7 \\
\hline Fair and objective & 67 & 23 & 10 & 0 & 0 \\
\hline Self confidence & 54 & 26 & 8 & 8 & 4 \\
\hline It will be consistence & 43 & 27 & 12 & 8 & 10 \\
\hline It helps students' to better understand & 34 & 26 & 15 & 15 & 10 \\
\hline Requires the students to study hard & 48 & 22 & 10 & 7 & 3 \\
\hline Can't cheat the answers & 76 & 24 & 0 & 0 & 0 \\
\hline Tell me own progress & 81 & 19 & 10 & 0 & 0 \\
\hline
\end{tabular}

Based on the questionnaire results that have been given to 119 respondents in three classes, the influences of Computer-assisted assessment (CAA) for learning English at Nusa Dua Vocational high School are:

1. Computer-assisted assessment (CAA) can improve student learning achievement. From 119 respondents, $45 \%$ or 55 students have been able to improve their learning achievement by increasing scores better in previous evaluation.

2. Computer-assisted assessment (CAA) can help the student's better understanding about vocabulary and grammatical English tested. In addition, students can directly improve skills in the use of computer systems. From 119 respondents, 63 students or $53 \%$ of students have been helped in understanding the subjects tested and can use the computer system properly.

3. Computer-assisted assessment (CAA) can increase four skills in learning English, especially in listening skills. In listening skills students can hear recordings of native speakers in communication, so students can know the pronunciation of English naturally. Even though skill speaking cannot be maximally evaluated, students can interpret it with reading and writing skills. From 119 respondents, $28 \%$ or 34 of them could improve their English skills.

4. Familiarizing, and training students to be honest. Students can immediately find out the results of the evaluation that has been done. So that students get an objective assessment according to their own abilities. From 119 respondents $63 \%$ of students claimed to have received an objective assessment during the evaluation process.

5. Students can increase their self-confidence, because in online assessment, students are required to work on all questions according to their own abilities and believe in their own answers. From 119 respondents, 54\% of students have been able to increase their confidence. Evidenced by the choice of answers that are in accordance with the knowledge they have.

6. Students can be more consistent in choosing answers in the questions given. In online assessment, students cannot change the answer that has been chosen if the time has expired. From 119 respondents, 43\% of them have been consistent in answering questions.

7. Students better understand the material in the questions given, so students are more careful in answering questions. From 119 respondents, only $34 \%$ of students or 40 students were able to understand the subject matter well.

8. It can express themselves, know personal abilities, so as to achieve satisfactory values, students must study hard, whether it's about grammatical or reading. Of the 119 respondents, $48 \%$ of them had studied hard to take the online exam.

9. The purity of the test scores is also higher, because each question on the screen is random and it makes it difficult for students to copy the answers to their friends. Teachers are easier to monitor the student. There are no books is needed on a table, so the opportunity to copy the book can be minimized. From 119 respondents $76 \%$ of respondents said online assessments can increase the purity of the test scores.

10. It can tell students directly about the progress that has been obtained for one semester. Around $81 \%$ of respondents can know in advance the progress that is obtained. $29 \%$ of them claimed that they could not know the progress they got directly because of technical constraints.

\section{CONCLUSION}

Based on our review and study result, there are some influences that found. The Computer-assisted assessment (CAA) systematics is held with the aim that students 
become more critical and independent in solving the questions given. Computer-assisted assessment (CAA) can improve student learning achievement. The student can better understanding about vocabulary and grammatical tested trough increasing four skills in learning English. It can express themselves, know personal abilities and the purity of the test scores is also higher, because each question on the screen is random and it makes it difficult for students to copy the answers to their friends. Thus computer-based items (relative to paper) may increase the transition time and memory focus on individual items (Clariana, 1997).

\section{REFERENCES}

Beaton, A., \& Zwick, R. (1990). The effect of changes in the National Assessment: Disentangling the NA EP 1985-86 reading anomaly. Princeton, NJ: Educational Testing Service.

Brown, S., \& Knight, P. (1995). Assessment in higher education. London: Kogan Page.

Bull, J., \& McKenna, C. (2001). Blueprint for computer-assisted assessment.

Clariana, R.B. (1997). Considering learning style in computer-assisted learning. British Journal of Educational Technology, 28, 66-68.

Haas, C., \& Hayes, R. (1986). What did I just say? Reading problems in writing with the machine. Research in the Teaching of English, 20, 22-35.

Karakaya, Z. (2001). Development and implementation of an on-line exam for a programming language course. Ankara: Metu.

Özden, Yasar et all. (2004). Students' Perceptions of Online Assessment: A Case Study. Journal of distance education revue de l'éducation à distance spring/printemps 2004 vol. 19, no 2, 77-9 